\title{
Physicochemical characteristics of lactic acid fermented Seomaeyaksuk (Artemisia argyi H) Sikhye added with different addition ratio of MSG
}

\author{
Jeong Yeon Shin ${ }^{1}$, Jung Hye Shin ${ }^{2}$, Min Jung Kang ${ }^{2}$, Myung Hyo Choi ${ }^{2}$, \\ Hee Rin Park ${ }^{1}$, Jine Shang Choi ${ }^{1}$, Won Yeol Bae ${ }^{3}$, Won Tak Seo ${ }^{1 *}$ \\ ${ }^{1}$ Department of Food Science, Gyeongnam National University of Science and Technology, Jinju 52725, Korea \\ ${ }^{2}$ Namhae Garlic Research Institute, Namhae 52430, Korea \\ ${ }^{3}$ Department of Food technology, Gyeongsang National University, Jinju 52828, Korea
}

\section{MSG 첨가 비율을 달리한 섬애약쑥(Artemisia argyi H) 식혜의 유산균 발효에 따른 이화학적 특성}

\author{
신정연 $^{1} \cdot$ 신정혜 $^{2} \cdot$ 강민정 $^{2} \cdot$ 최명 효 ${ }^{2} \cdot$ 박희린 $^{1} \cdot$ 최진상 ${ }^{1} \cdot$ 배원열 $^{3} \cdot$ 서원택 $^{1 *}$ \\ ${ }^{1}$ 경남과학기술대학교, ${ }^{2}$ (재) 남해마늘연구소, ${ }^{3}$ 경상대학교
}

\begin{abstract}
For the production of y-aminobutyric acid (GABA) contents increased Seomaeyaksuk fermentant, 0, 0.25, 0.5 and $1.0 \%$ of monosodium galutamate (MSG) was added in Seomaeyaksuk water extract $15 \%$ contained Sikhye and inoculated with Lactobacillus brevis (KI271266). Physicochemical properties were sampling and analyzed at each 1 day during 3 days fermentation. Goes on fermentation periods, the turbidity was gradually reduced, but lightness and the yellowness was increased, redness was decreased. Soluble solid was also decreased. The reducing sugars content were also decreased during fermentation. $\mathrm{pH}$ was 4.65-4.83 before fermentation but it was lower 3.15-3.68 after three days fermentation. The GABA contents increased by fermentation periods and it was the highest in MSG 1.0\% added sample $(354.38 \mathrm{mg} / \mathrm{L})$. Fructose, glucose and sucrose contents were 50-67\% decreased at three days fermentation than before fermentation. Among the organic acids, propionic acid, oxalic acid, citric acid and fumaric acid contents were decreased and lactic acid, acetic acid and succinic acid were increased during fermentation periods. Contents of total polyphenol and DPPH radical scavenging activity were the highest in MSG $0.5 \%$ added sample. From these results, we confirmed that increasing of GABA content when the manufacturing of Seomaeyaksuk lactic acid fermentation product, is possibile by addition of MSG without affecting physicochemical characteristics.
\end{abstract}

Key words : Seomaeyaksuk, lactic acid, fermentation, GABA, monosodium galutamate

\section{서 론}

다양한 외부의 환경적 인자들로부터 육체적 스트레스를 받고 있는 현대인들은 인체에 유용한 활성을 가지는 식품류

*Corresponding author. E-mail : wtseo@gntech.ac.kr Phone : 82-10-4571-3276, Fax : 82-55-751-3279

Received 12 October 2016; Revised 23 February 2017; Accepted 24 March 2017.

Copyright (C) The Korean Society of Food Preservation. All rights reserved.
를 섭취함으로써 건강을 유지하고자 노력하고 있다. 이러 한 측면에서, 현대인의 식품소비 트랜드는 기존의 식품첨 가물이 함유된 식품류 보다는 자연식품을 그대로 섭취하거 나, 가공기술을 통해 기존의 식품성분 중 유용성분만을 분 리거나 생물전환을 통해 유용성분을 증가시켜 섭취하는 방향으로 변화하고 있다. 식품 중의 유용성분을 증가시키 는 대표적인 가공방법 중 하나인 발효는 식품자체에 부착되 어 있는 효모, 젖산균 및 초산균을 이용하여 식품에 물리적 조작을 최소화함으로써 유용성분을 얻을 수 있는 장점이 있다. 이 중 젖산발효는 우리나라뿐만 아니라 세계 각국에 
서 발효식품 제조에 이용하고 있으며, 젖산균이 당을 이용 해 산을 생성함으로써 저장성을 높이는 목적으로 이용되어 왔으나 젖산 발효식품의 다양한 건강 증진 기능성이 알려지 면서 전 세계적으로 섭취되는 대표적인 발효 식품으로 자리 매김 하고 있다(1).

젖산발효 식품은 정장작용과 더불어 소화흡수 축진, 변 비, 설사 등의 개선, 혈중 콜레스테롤의 저하작용 및 면역증 진 작용 등이 있는 것으로 알려져 있어 유제품을 중심으로 많은 연구들이 진행되어 왔으며 $(2,3)$, 최근에는 다양한 식 물성 원료의 쥬스나 추출물을 젖산발효 시키는 연구들이 진행되고 있다. 당근 주스는 젖산발효를 통해 침전물 억제 및 물성 개선과 더불어 냉장 저장 동안의 품질유지가 가능 하며(4), 인삼열매 추출물을 젖산발효 함으로써 사포닌 함 량과 항산화활성이 증가되었다는 보고가 있다(5). 뽕잎의 젖산발효 추출액은 유기산과 더불어 폴리페놀화합물, 안토 시아닌의 함량이 높고, 소화효소의 활성능을 지닌다는 보 고(6)도 있다. 또한 $L b$. brevi, $L b$. plantarum과 같은 젖산균주 는 발효과정을 통해 $\gamma$-aminobutyric acid(GABA)와 같은 생 리활성 물질의 생성을 증가시키는 것으로 알려져 있어 $(7,8)$ 다양한 소재와 균주를 중심으로 한 젖산 발효물의 효능검증 에 대한 연구가 요구되고 있다.

$\mathrm{GABA}$ 는 억제성 신경전달물질로 뇌세포 대사기능 촉진 을 통한 신경안정작용, 뇌 혈류 개선을 통한 산소 공급량 증가, 스트레스 해소, 기억력 증진, 불안장해 해소, 우울증 완화, 알코올 대사 촉진, 성장호르몬 분비 촉진의 기능이 있으며, 불면, 중풍 및 치매예방, 비만방지, 갱년기 장애 개선, 뇌졸중, 결장암, 대장암 세포의 증식억제 등에 효과가 있는 것으로 알려져 있다(9-13). 이처럼 다양한 기능성을 가지는 GABA는 4-aminobutyric acid가 L-glutamate의 영구 적인 탈탄산화를 촉진하는 glutamate decarboxylase(GAD) 에 의해 pyridoxal-5'-phosphate dependent 경로로 합성되는 데(14), GABA 합성이 필요할 때 뇌 조직내에서 apoenzyme 상태로 존재하던 GAD가 PLP에 의해 활성화 되는 것으로 알려져 있다(15).

$\mathrm{GAD}$ 와 $\mathrm{GABA}$ 는 미생물과 동물세포 및 식물세포에까지 널리 분포하는데, 식물체 내에는 일반미에 $1-4 \mathrm{mg} / 100 \mathrm{~g}$, 현미에 4-8 mg/100 g, 녹차에 35-205 mg/100 g 함유되어 있으나 그 함량이 낮아 $100 \% \mathrm{GABA}$ 를 기준으로 생리적 효능을 얻을 수 있는 하루의 섭취량인 50-100 mg 정도를 섭취하는 데는 어려움이 있으며, 비타민 부족 등은 체내 $\mathrm{GABA}$ 의 부족을 일으키기도 한다(16,17). 이러한 측면에서 식품 내에 존재하는 $\mathrm{GABA}$ 의 함량을 증가시키기 위한 연구 들이 진행되고 있다. GABA의 함량 증진을 위한 가공방법 으로는 녹차와 같은 고체 식품의 경우 질소가스 농도를 높여 밀봉하여 혐기처리 하는 방법, 발아 현미와 같이 발아 과정에서 세포내 칼륨 증가를 통한 $\mathrm{GABA}$ 의 축적 및 세균 에 의한 발효과정을 통한 생성 방법 등이 제시되고 있다
$(18,19)$. 이 중 가장 효율적인 방법인 발효는 세균의 증식에 의해 생성된 산에 의해 $\mathrm{GAD}$ 발현의 최적 $\mathrm{pH}$ 인 3.8-4.6의 환경을 용이하게 제공하므로 젖산균 발효물은 $\mathrm{GAD}$ 의 좋 은 급원이 되며, $\mathrm{GAD}$ 의 생성은 질소원이 존재할 경우 자연 스럽게 $\mathrm{GABA}$ 함량을 증가시키게 된다 $(20,8)$.

본 연구에서는 황해쑥의 일종으로 품종보호 등록된 섬애 약숙을 이용한 가공품 개발 연구의 일환으로 섬애약쑥 추출 물이 함유된 쑥 식혜에 monosodium glutamate(MSG)를 농 도별로 첨가한 것을 발효 기질로 하여 김치로부터 분리한 젖산균주로 발효하면서 이화학적 특성을 분석함으로써 발 효물의 $\mathrm{GABA}$ 생성량 증진 조건 설정을 위한 기초 자료를 확보하고자 하였다.

\section{재료 및 방법}

\section{실험재료}

실험에 사용된 섬애약쑥(Seomaeyakssuk, Artemisia argyi H.)은 2014년 6월경 경남 남해군 설천면에서 재배되고 있는 것을 채취하여 이물질을 제거한 후, 흐르는 물에서 2회 세척 하였다. 이를 $18-24^{\circ} \mathrm{C}$ 의 그늘지고 바람이 잘 통하는 실내에 서 매일 1 회씩 위치를 바꾸거나 뒤집어 주면서 14 일간 자연 건조 시켰다. 건조가 완료된 섬애약쑥은 비닐팩에 담아 흡 습을 방지하여 상온에 보관하면서 시료로 사용하였다.

식혜 제조를 위한 맥아는 푸른들 농산(주)(Andong, Korea)의 제품을 구입하여 균일하게 체질한 후 고운분말을 사용하였고, 고두밥 제조는 시판되는 고성 청결미를 이용 하였다.

\section{섬애약쑥 추출물의 제조}

식혜 제조에 사용된 섬애약쑥 추출물은 음건 쑥 무게 대비 정제수를 10 배 가하여 2 시간 이상 침지시켜 충분히 수화시킨 후 autoclave를 이용하여 $121^{\circ} \mathrm{C}$ 에서 30 분간 고온 추출하였다. 추출물은 cheese cloth로 여과하여 사용하였다.

\section{유산균 발효균주}

유산균 발효 균주는 일반 가정에서 수거한 김치 70 여종 을 Lactobacilli MRS 고체배지에 도말하여 $30^{\circ} \mathrm{C}$ 에서 24 시간 배양한 후 성장된 균체를 동일배지에 1 loop 접종하고 $30^{\circ} \mathrm{C}$ 에서 24 시간 재 배양하여 약 200 여종의 유산균을 분리하였 다. 각 분리된 균주는 Lactobacilli MRS 액체배지에서 $30^{\circ} \mathrm{C}$ 에서 24시간 배양한 후 $660 \mathrm{~nm}$ 에서 흡광도 값이 1이 되도록 조절하였다. 이것을 $1 \% \mathrm{MSG}$ 를 함유한 Lactobacilli $\mathrm{MRS}$ 액체배지에 $1 \%$ 접종하여 $30^{\circ} \mathrm{C}$ 에서 24 시간 $150 \mathrm{rpm}$ 으로 진탕배양 한 다음 배양 중의 GABA 생성 유무를 TLC plate(TLC Silica gel $60 \mathrm{~F}_{254}$, glass plates $20 \times 20 \mathrm{~cm}$, Merck, Darmstadt, Germany)상에서 확인하였다. GABA 표준물질 
과 동일한 Rf 값을 나타내는 물질을 가장 많이 생성한 균주 3종(자체 명명: LAB86GA, LAB151GA, LAB204GA)을 확 인한 후 한국미생물보존센터에 의뢰하여 $16 \mathrm{~S}$ rRNA partial sequencing을 통해 해당 균주를 동정하였다. 동정 결과 3 종 의 균주 모두 동일하게 Lactobacillus brevis로 확인되었으므 로 TLC 상에서 가장 큰 spot을 나타낸 LAB86GA를 유산균 발효 균주로 사용하였다. LAB86GA 균주는 Lactobacilli MRS 액체배지에서 종배양하여 유산균 발효물 제조에 사용 하였다.

섬애약숙 식혜를 이용한 유산균 발효물의 제조

고두밥 $800 \mathrm{~g}$, 체에 내린 엿기름 분말 $400 \mathrm{~g}$, 쑥 추출액 $600 \mathrm{~g}$ 및 정제수 $2,200 \mathrm{~g}$ 을 충분히 혼합하여 $60 \pm 3^{\circ} \mathrm{C}$ 의 항온 수조 내에서 내용물이 모두 잠기게 중탕하면서 5시간 동안 당화 시킨 후 $90^{\circ} \mathrm{C}$ 이상에서 10 분간 가열하여 섬애약쑥 식혜를 완성하였다. 이것을 무균대에서 자연냉각시켜 약 $30^{\circ} \mathrm{C}$ 가 되면 종 배양한 유산균주를 당화액의 $5 \%(\mathrm{v} / \mathrm{v})$ 비율 로 접종하였다. MSG 첨가비율에 따른 유산균 발효물의 품질특성 비교를 위하여 예비실험을 통해 식혜의 맛을 평가 한 결과 $\mathrm{MSG}$ 를 $1 \%$ 이상 첨가하였을 때는 맛에 변조가 있었으므로 $\mathrm{MSG}$ 는 그 이하의 농도인 $0,0.25,0.5,1 \%$ 씩 함유하도록 각각의 섬 애약숙 식혜에 첨가하였으며, 이를 $30^{\circ} \mathrm{C}$ 에서 배양하면서 접종 직후(0시간), $12,24,48$ 및 72시 간에 시료를 취하여 실험하였다.

\section{탁도, 색도 및 $\mathrm{pH}$}

탁도는 침출 시료 일정량을 취하여 분광광도계(OPtizen ALPHA, Mecasys Co., Ltd., Daejeon, Korea)를 이용하여 $600 \mathrm{~nm}$ 에서 탁도를 측정하여 흡광도 값으로 나타내었다. 추출액의 색도는 색차계(Ultra Scan VIS, Hunter Associates Laboratory Inc., Reston, VA, USA)를 사용하여 5회 반복하 여 측정한 후 Hunter scale에 의해 L(lightness), a(redness), $\mathrm{b}$ (yellow) 값으로 표시하였다. 이 때 사용한 표준백판의 $\mathrm{L}$, $\mathrm{a}$ 및 $\mathrm{b}$ 값은 각각 $99.42,-0.12$ 및 +0.03 였다.

$\mathrm{pH}$ 는 시료액을 여과하여 $\mathrm{pH}$ meter(Model 720, Thermo Orion, Beverly, MA, USA)을 이용하여 3회 반복 측정하 였다.

\section{가용성 고형분 및 환원당 함량}

가용성고형분은 여과한 시료액을 일정량 취하여 자동굴 절당도계(PR-201a, Atago, Tokyo, Japan)로 3회 반복 측정하 였다. 총당은 황산 페놀법으로 측정하였다.

환원당은 3,5-dinitrosalicylic acid(DNS)에 의한 비색법에 따라 침출액 $1 \mathrm{~mL}$ 에 DNS 시약 $3 \mathrm{~mL}$ 을 가하고 $97^{\circ} \mathrm{C}$ 에서 15 분간 가열한 다음 빙수 중에서 냉각한 후 $570 \mathrm{~nm}$ 에서 흡광도를 측정하였다. 환원당의 함량은 glucose(SigmaAldrich Co., Ltd., St. Louis, MO, USA)를 표준물질로 하여
작성한 표준검량곡선으로 부터 산정하였다.

\section{$\mathrm{GABA}$ 정량}

$\mathrm{GABA}$ 의 함량은 효소분석 방법을 이용하여 정량하였다 (22). 액상 시료 $1 \mathrm{~mL}$ 에 $70 \mathrm{mM} \mathrm{LaCl} 31 \mathrm{~mL}$ 를 가하여 15 분 동안 잘 섞어준 후 $3,500 \times g$ 에서 5 분간 원심분리 하였다. 상등액 $400 \mu \mathrm{L}$ 를 취하여 $0.1 \mathrm{M} \mathrm{KOH} 160 \mu \mathrm{L}$ 를 미리 넣어둔 centrifuge tube에 넣어 5 분간 교반하였다. 다시 $3,500 \times \mathrm{g}$ 에 서 5 분간 원심 분리한 상등액 $50 \mu \mathrm{L}$ 에 $0.5 \mathrm{M} \mathrm{K}_{4} \mathrm{P}_{2} \mathrm{O}_{7}$ 완충용 제공액 $(\mathrm{pH}$ 8.6) $50 \mu \mathrm{L}, 4 \mathrm{mM}$ NADP $150 \mu \mathrm{L}$ 를 첨가한 후, 2.0 unit $/ \mathrm{mL}$ enzymatic GABase assa $50 \mu \mathrm{L}$ 를 혼합하여 340 $\mathrm{nm}$ 에서 흡광도를 측정하였으며(initial A), $20 \mathrm{mM} \mathrm{a}$ -ketoglutarate를 $50 \mu \mathrm{L}$ 넣고 $25^{\circ} \mathrm{C}$ 에서 60 분 동안 반응시킨 후 $340 \mathrm{~nm}$ 에서 흡광도를 측정(final A)하였다. 농도별 GABA(Sigma-Aldrich Co., Ltd.)를 동일한 조건에서 분석한 표준검량곡선에 측정된 흡광도(final A-initial A)를 대입하 여 생성된 $\mathrm{GABA}$ 함량을 측정하였다.

\section{유리당 함량 분석}

시료 $5 \mathrm{~g}$ 에 3 차 증류수 $30 \mathrm{~mL}$ 을 가하고, 30 분간 sonication 하였다. Filter paper로 여과한 후, $0.45 \mu \mathrm{m}$ syringe filter로 여과하여 HPLC-ELSD(Agilent 1260 infinity, Agilent, Santa Clara, CA, USA)로 분석하였다. Analytical column은 COSMOSIL Sugar-D $(4.6 \times 250 \mathrm{~mm}$, Nacalai Tesque Inc., Kyoto, Japan)를 사용하였고, 이동상은 water와 acetonitrile 을 $3: 7(\mathrm{v} / \mathrm{v})$ 의 비율로 혼합한 것을 사용하였다. 이동상의 속도는 $1.0 \mathrm{~mL} / \mathrm{min}$, 시료 주입량은 $10 \mu \mathrm{L}$, 검출기는 $\mathrm{ELSD}$ 를 사용하였으며, 분석 온도는 $30^{\circ} \mathrm{C}$, 가스는 질소를 사용하 였다.

\section{유기산의 함량}

각각의 시료를 여과지로 여과한 후 여액을 취하여 0.45 $\mu \mathrm{m}$ membrane filter로 재여과한 다음 HPLC로 분석하였다. 분석용 컬럼은 Watchers 120 ODS-BP $(4.6 \times 250 \mathrm{~mm}, 5 \mu \mathrm{m}$, Watchers, Daiso Chemical Co., Tokyo, Japan)를 사용하였고, 이동상 용매는 $0.1 \% \mathrm{H}_{3} \mathrm{PO}_{4}$ 수용액을 $0.5 \mathrm{~mL} / \mathrm{min}$ 의 속도로 주입하였으며, 분석온도는 $30^{\circ} \mathrm{C}$ 를 유지하였고, $10 \mu \mathrm{L}$ 의 시 료를 주입하여 $210 \mathrm{~nm}$ 에서 UV 검출기를 이용하여 검출하 였다. 총 10 종의 유기산(citric acid, oxalic acid, tartaric acid, formic acid, malic acid, lactic acid, acetic acid, fumatic acid, succinic acid, propionic acid) 표준물질을 시료와 동일한 조 건에서 분석하여 머무름 시간 비교해 확인하였으며, 각각 의 검량곡선으로부터 그 함량을 산출하였다.

\section{총 폴리페놀 화합물의 함량}

총 폴리페놀 화합물의 함량은 Folin-Ciocalteu법(22)으로 측정하였다. 시료를 $2,700 \times g$ 에서 15 분간 원심분리한 상등 
액 $0.5 \mathrm{~mL}$ 과 $25 \% \mathrm{Na}_{2} \mathrm{CO}_{3}$ 용액 $0.5 \mathrm{~mL}$ 을 혼합하여 3 분간 정치시켰다. 다시 $2 \mathrm{~N}$ Folin-Ciocalteu phenol 시약 $0.25 \mathrm{~mL}$ 을 첨가하여 혼합한 다음 $30^{\circ} \mathrm{C}$ 에서 1 시간 동안 정치시켜 발색시켰다. 발색된 청색을 분광광도계를 이용하여 $750 \mathrm{~nm}$ 에서 흡광도를 측정하였다. 이때 총 폴리페놀 화합물의 함 량은 gallic acid(Sigma-Aldrich Co., Ltd.)를 이용하여 작성한 표준곡선으로부터 산출하여 gallic acid에 상당하는 량으로 계산하였다. 각 실험은 3회 반복하여 평균값으로 나타내 었다.

\section{$\mathrm{DPPH}$ 라디칼 소거활성}

Blois의 방법(23)을 변형하여 DPPH 라디칼 소거활성에 의한 항산화 활성을 측정하였다. 에탄올로 $1.5 \times 10^{-4} \mathrm{M}$ 농도 가 되도록 조절한 $\mathrm{DPPH}(1,1$-diphenyl-2-picryhdrazyl, $\mathrm{C}_{18} \mathrm{H}_{12} \mathrm{~N}_{5} \mathrm{O}_{6}$ ) 용액 $0.8 \mathrm{~mL}$ 에 $11,000 \times g$ 로 3 분간 원심분리 한 시료 상등액 $0.2 \mathrm{~mL}$ 를 가하고 10 초간 균질화시킨 다음 실온에서 30 분간 방치한 후 분광광도계 $525 \mathrm{~nm}$ 에서 흡광도 를 측정하였다. 음성대조군은 시료대신에 증류수 $0.2 \mathrm{~mL}$ 를 가하여 동일하게 실험하였다. DPPH 라디칼 소거 활성은 실험구와 음성대조구의 흡광도를 구하여 아래와 같은 식으 로 계산하여 백분율(\%)로 표시하였다. 각 실험은 3회 반복 하여 평균값으로 나타내었다.

\section{통계처리}

모든 실험은 3회 이상 반복하여 실시하였으며 실험으로 부터 얻은 결과는 SPSS 12.0(IBM, Armonk, NY, USA)을 사용하여 분석하였다. 결과치는 실험군당 평균 \pm 표준편차 로 표시하였고, 통계적 유의성 검정은 일원배치 분산분석 (one-way analysis of variance)을 한 후 $\mathrm{p}<0.05$ 수준에서 Duncan's multiple range test를 시행하였다.

\section{결과 및 고찰}

발효용 유산균주의 분리동정

김치로부터 분리한 200 여종의 유산균주 배양액을 GABA 표준물질과 함께 TLC plate상에서 전개시켜 GABA 생성 정도를 확인하여 큰 spot를 나타내는 균주 3종을 선발 하였다(Fig. 1). 이들 균주 3종을 분리 배양하여 $16 \mathrm{~s} \mathrm{rRNA}$ 의 부분 염기서열 분석 및 동정 결과는 Fig. 2와 같다. GenBank 의 공지서열과 서열 상동성을 비교한 결과 3 종의 균주 모두 $100 \%$ Lactobacillus brevis(KI271266)와 일치하여 동일한 균주임이 확인되었다.

\section{탁도 및 색도의 변화}

섬애약쑥 추출물을 첨가하여 제조한 식혜에 $\mathrm{MSG}$ 를 농 도별로 첨가하고 유산균주를 접종하여 $30^{\circ} \mathrm{C}$ 에서 3 일간 배
양하면서 탁도를 분석한 결과는 Table 1과 같다. 발효 초기 탁도는 0.25-0.81이던 것이 발효 1일째에는 1.09-1.93으로 흡광도 값이 크게 증가하여 모든 시료에서 발효 1 일에 가장 높았고, 그 이후부터는 점차 감소하여 발효 3일에는 0.63-1.38의 범위로 낮아졌다. MSG를 $0.25 \%$ 첨가하였을 때는 무첨가군과 유의적인 차이가 없었으나 $\mathrm{MSG}$ 를 $0.5 \%$ 이상을 첨가함으로써 탁도는 더 증가하여 $\mathrm{MSG}$ 의 첨가량 이 많을수록 탁도도 증가하였다. 발효 3일 후 MSG $0.25 \%$ 첨가군의 탁도는 흡광도 값으로 0.63 이었으나 $0.5 \%$ 첨가군 에서는 유의적으로 높아 0.83 이었고, $1.0 \%$ 첨가군에서는 1.38 로 가장 높았다.

섬애약쑥 추출물을 $15 \%$ 첨가하여 제조한 쑥 식혜를 발효 기질로 하고 김치로부터 분리한 GABA 생성능이 우수한 균주를 접종하여 3 일간 발효하면서 섬애약쑥 발효물의 색 도를 분석한 결과는 Table 2 와 같다. 발효기간이 경과할수 록 발효물의 명도값은 증가하는 경향을 나타내었으며, $\mathrm{MSG}$ 의 첨가량이 많을수록 명도는 오히려 더 낮았다. 즉, $\mathrm{MSG}$ 를 첨가하지 않은 발효물의 명도는 발효 0 일차에 35.61 이던 것이 발효 3일에는 41.92로 증가하였으며, MSG $0.5 \%$ 첨가 발효군에서는 발효 0 일차에 30.03 이던 것이 발효 3 일에는 40.24 로 증가하였다. 적색도는 발효기간이 경과할 수록 점차 감소하는 경향을 나타내었는데, 발효 0 일차에 1.74-1.90이던 것이 발효 3일에는 0.92-1.39로 증가하였다. 황색도는 발효기간이 경과할수록 점차 증가하는 경향을 보여 발효 0 일차에는 8.01-8.46의 범위로 시료간에는 유의 적인 차이가 없었으나 발효 3일에는 14.79-16.18로 증가하 였으며, MSG 무첨가군에서 가장 높았다.

\section{$\mathrm{pH}$ 의 변화}

$\mathrm{MSG}$ 의 첨가비율을 달리한 섬애약쑥 식혜에 유산균을 접종하여 3 일간 발효시키면서 $\mathrm{pH}$ 의 변화를 분석한 결과는

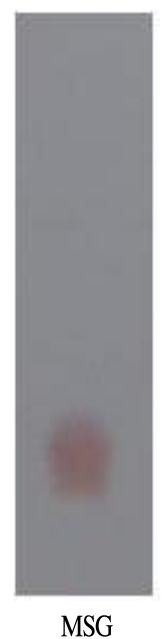

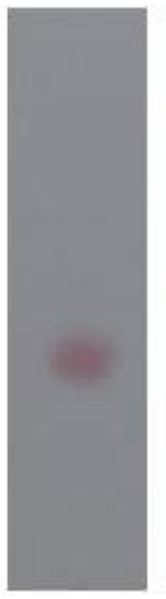

GABA

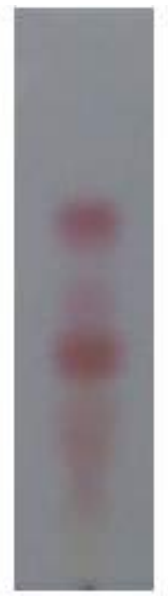

LAB86GA

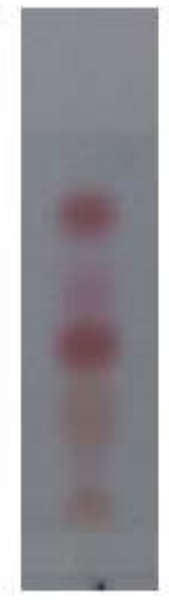

LAB151GA LAB204GA
Fig. 1. TLC profile of monosodium glutamate (MSG) and $\gamma$ -aminobutyric acid (GABA) from the cultures of lactic acid bacteria isolated from kimchi. 
(A)

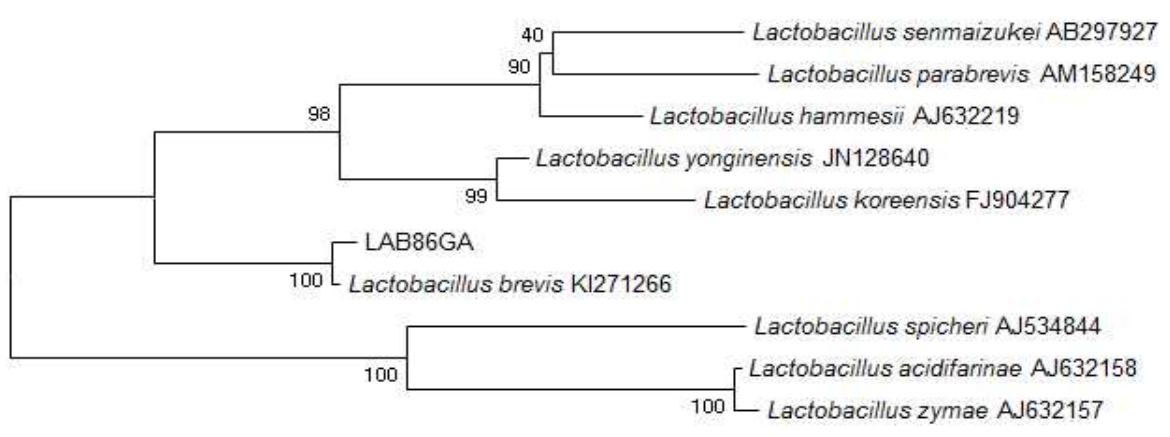

$\longmapsto 0,002$

(B)

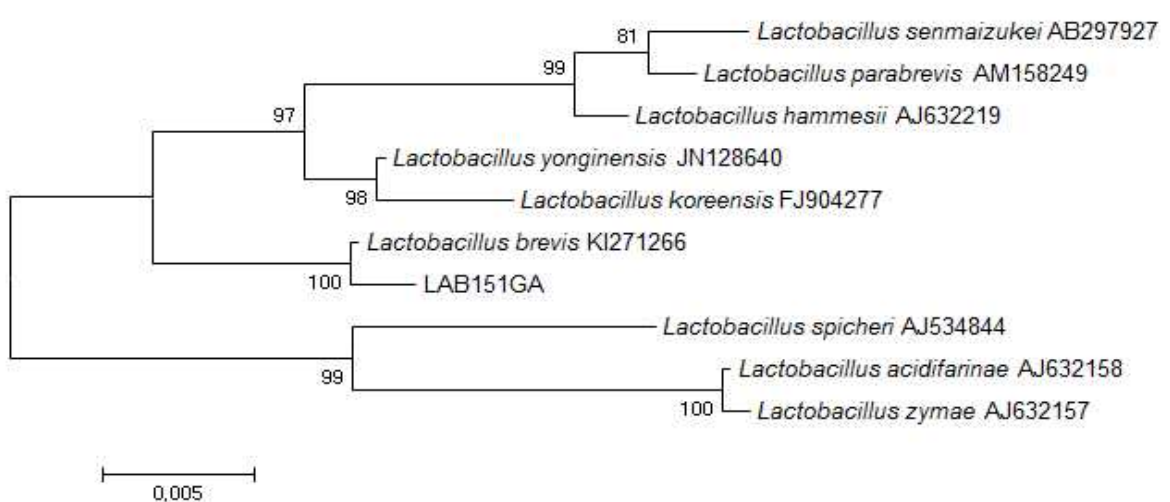

(C)

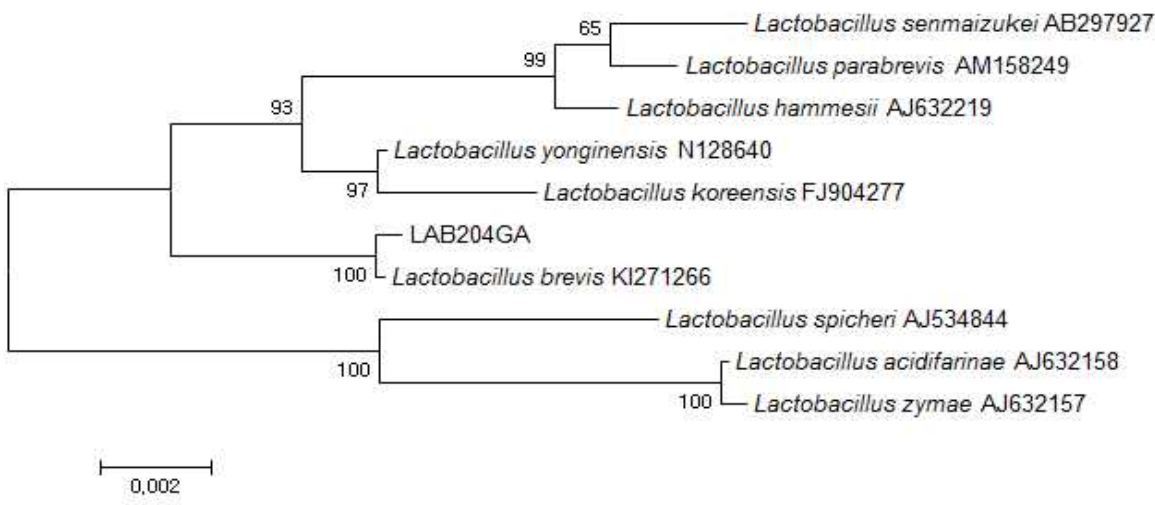

Fig. 2. Phylogenetic tree based on 16s rRNA sequence of 3 strains (A, LAB86GA; B, LAB151GA; C, LAB204 GA) from kimchi. The blanching pattern was generated by neighbor-joining method. Bar, 0.01 nucleotide substitution per position.

Table 1. Changes in turbidity of lactic acid fermented Sikhye added with Seomaeyaksuk extract and different ratio of MSG

(OD value)

\begin{tabular}{ccccc}
\hline \multirow{2}{*}{$\begin{array}{c}\text { Fermentation period } \\
\text { (day) }\end{array}$} & \multicolumn{4}{c}{ MSG addition ratio (\%) } \\
\cline { 2 - 5 } & 0 & 0.25 & 0.5 & $0.86 \pm 0.12^{\mathrm{dA}}$ \\
\hline 0 & $0.25 \pm 0.01^{1) \mathrm{a} 2) \mathrm{A} 3)}$ & $0.39 \pm 0.01^{\mathrm{bA}}$ & $0.81 \pm 0.04^{\mathrm{cA}}$ \\
1 & $1.09 \pm 0.03^{\mathrm{aD}}$ & $1.54 \pm 0.06^{\mathrm{aB}}$ & $1.77 \pm 0.02^{\mathrm{aC}}$ & $1.93 \pm 0.02^{\mathrm{aD}}$ \\
2 & $0.87 \pm 0.02^{\mathrm{bC}}$ & $0.72 \pm 0.01^{\mathrm{aA}}$ & $1.50 \pm 0.10^{\mathrm{cB}}$ & $1.81 \pm 0.01^{\mathrm{dC}}$ \\
3 & $0.66 \pm 0.02^{\mathrm{aB}}$ & $0.63 \pm 0.07^{\mathrm{aA}}$ & $0.83 \pm 0.07^{\mathrm{bA}}$ & $1.38 \pm 0.18^{\mathrm{cB}}$ \\
\hline
\end{tabular}

${ }^{1)}$ Each value is a mean \pm SD of 5 samples.

${ }^{2) a-d}$ Means with different letters in the same row are significantly different at $p<0.05$ by Duncan's multiple range test.

${ }^{3) A-D}$ Means with different letters in the same column are significantly different at $p<0.05$ by Duncan's multiple range test. 
Table 2. Changes in Hunter's color value of lactic acid fermented Sikhye added with Seomaeyaksuk extract and MSG

\begin{tabular}{|c|c|c|c|c|c|}
\hline \multirow{2}{*}{\multicolumn{2}{|c|}{$\begin{array}{l}\text { Fermentation period } \\
(\text { day })\end{array}$}} & \multicolumn{4}{|c|}{ MSG addition ratio (\%) } \\
\hline & & 0 & 0.25 & 0.5 & 1.0 \\
\hline \multirow{4}{*}{$\mathrm{L}$} & 0 & $35.61 \pm 0.40^{1 /(2) / A 3)}$ & $32.12 \pm 0.36^{\mathrm{bA}}$ & $30.03 \pm 0.60^{\mathrm{aA}}$ & $30.55 \pm 0.45^{\mathrm{aA}}$ \\
\hline & 1 & $38.11 \pm 0.13^{\mathrm{dB}}$ & $32.48 \pm 0.19^{\mathrm{bA}}$ & $31.51 \pm 0.06^{\mathrm{B}}$ & $35.56 \pm 0.16^{\mathrm{CB}}$ \\
\hline & 2 & $39.99 \pm 0.05^{\llcorner\mathrm{C}}$ & $35.71 \pm 0.27^{\mathrm{bB}}$ & $35.04 \pm 0.12^{\mathrm{aC}}$ & $35.83 \pm 0.15^{\mathrm{bB}}$ \\
\hline & 3 & $41.92 \pm 0.40^{\mathrm{cD}}$ & $39.45 \pm 0.17^{\mathrm{aC}}$ & $40.27 \pm 0.20^{6 \mathrm{D}}$ & $42.19 \pm 0.12^{\mathrm{CC}}$ \\
\hline \multirow{4}{*}{$\mathrm{a}$} & 0 & $1.74 \pm 0.10^{\mathrm{aC}}$ & $1.86 \pm 0.03^{\mathrm{abB}}$ & $1.88 \pm 0.07^{\mathrm{bB}}$ & $1.90 \pm 0.04^{b D}$ \\
\hline & 1 & $1.61 \pm 0.05^{\mathrm{aBC}}$ & $1.85 \pm 0.02^{\mathrm{bB}}$ & $1.82 \pm 0.03^{\mathrm{bB}}$ & $1.78 \pm 0.04^{\mathrm{bC}}$ \\
\hline & 2 & $1.56 \pm 0.09^{\mathrm{cB}}$ & $1.39 \pm 0.08^{\mathrm{abA}}$ & $1.41 \pm 0.03^{\mathrm{bA}}$ & $1.28 \pm 0.03^{\mathrm{aB}}$ \\
\hline & 3 & $0.92 \pm 0.03^{\mathrm{aA}}$ & $1.39 \pm 0.10^{\mathrm{cA}}$ & $1.34 \pm 0.02^{\mathrm{cA}}$ & $1.21 \pm 0.02^{\mathrm{bA}}$ \\
\hline \multirow{4}{*}{$\mathrm{b}$} & 0 & $8.46 \pm 0.33^{\mathrm{aA}}$ & $8.10 \pm 0.09^{\mathrm{aA}}$ & $8.43 \pm 0.34^{\mathrm{aA}}$ & $8.01 \pm 0.13^{\mathrm{aA}}$ \\
\hline & 1 & $8.47 \pm 0.26^{\mathrm{aA}}$ & $9.19 \pm 0.42^{\mathrm{bB}}$ & $9.72 \pm 0.32^{\mathrm{bB}}$ & $9.63 \pm 0.14^{\mathrm{bB}}$ \\
\hline & 2 & $10.37 \pm 0.11^{\mathrm{aB}}$ & $10.53 \pm 0.41^{\mathrm{aC}}$ & $10.60 \pm 0.21^{\mathrm{aC}}$ & $10.71 \pm 0.07^{\mathrm{aC}}$ \\
\hline & 3 & $16.18 \pm 0.31^{\mathrm{bC}}$ & $16.13 \pm 0.32^{\mathrm{bD}}$ & $14.93 \pm 0.13^{\mathrm{aD}}$ & $14.79 \pm 0.52^{\mathrm{aD}}$ \\
\hline
\end{tabular}

${ }^{1)}$ Each value is a mean \pm SD of 5 samples.

2)-dMeans with different letters in the same row are significantly different at $\mathrm{p}<0.05$ by Duncan's multiple range test.

${ }^{3) A-D}$ Means with different letters in the same column are significantly different at $p<0.05$ by Duncan's multiple range test.

Table 3. Changes in $\mathrm{pH}$ of lactic acid fermented Sikhye added with Seomaeyaksuk extract and MSG

\begin{tabular}{ccccc}
\hline \multirow{2}{*}{$\begin{array}{c}\text { Fermentation period } \\
\text { (day) }\end{array}$} & \multicolumn{4}{c}{ MSG addition ratio (\%) } \\
\cline { 2 - 5 } & 0 & 0.25 & 0.5 & 1.0 \\
\hline 0 & $4.65 \pm 0.01^{1 \mathrm{da2}) \mathrm{C} 3)}$ & $4.70 \pm 0.02^{\mathrm{bD}}$ & $4.72 \pm 0.02^{\mathrm{bD}}$ & $4.83 \pm 0.01^{\mathrm{cD}}$ \\
1 & $3.41 \pm 0.01^{\mathrm{aB}}$ & $3.65 \pm 0.01^{\mathrm{bC}}$ & $3.70 \pm 0.01^{\mathrm{CC}}$ & $3.85 \pm 0.01^{\mathrm{dC}}$ \\
2 & $3.17 \pm 0.01^{\mathrm{aA}}$ & $3.52 \pm 0.01^{\mathrm{bB}}$ & $3.53 \pm 0.02^{\mathrm{bB}}$ & $3.70 \pm 0.01^{\mathrm{CB}}$ \\
3 & $3.15 \pm 0.02^{\mathrm{aA}}$ & $3.45 \pm 0.02^{\mathrm{AbA}}$ & $3.43 \pm 0.02^{\mathrm{bA}}$ & $3.68 \pm 0.01^{\mathrm{cA}}$ \\
\hline
\end{tabular}

${ }^{1)}$ Each value is a mean $\pm \mathrm{SD}$ of 5 samples.

${ }^{2) a-1}$ Means with different letters in the same row are significantly different at $p<0.05$ by Duncan's multiple range test.

${ }^{3) A-D}$ Means with different letters in the same column are significantly different at $p<0.05$ by Duncan's multiple range test.

Table 3과 같다. 발효 전 $\mathrm{pH}$ 는 4.65-4.83의 범위이던 것이 발효가 진행되면서 점차 산성화되어 발효 3일에는 3.153.68 의 범위였다.

6종의 과채 착즙액에 유산균을 접종하여 발효시켰을 때 $\mathrm{pH}$ 는 발효초기 4.94-5.02이던 것이 발효가 진행되면서 점 차 감소하는 경향을 나타내었다는 보고(24)는 본 연구와도 일치하는 경향이었다.

섬애약쑥 식혜의 $\mathrm{pH}$ 는 $\mathrm{MSG}$ 의 첨가농도가 많을수록 더 높았으며, 이러한 경향은 발효기간 동안 지속되었다. 3일간 의 발효 완료 후 $\mathrm{MSG}$ 무첨가군의 $\mathrm{pH}$ 는 3.15로 가장 낮았고, $1 \%$ 첨가군은 3.68 로 가장 높았다. 오미자 열매 추출액에 질소원으로 $\mathrm{MSG}$ 를 $2 \%$ 가하여 유산균 발효 시켰을 때 발효 가 진행되기 전에 $\mathrm{MSG}$ 만 첨가하여도 $\mathrm{pH}$ 가 3.14에서 4.16 으로 증가하였는데 이는 MSG가 중성아미노산이므로 산성 이 강한 오미자 추출액을 중화시키는 효과를 나타내기 때문 이라는 Lee 등(25)의 보고가 있다. 본 연구에서 발효 전
$\mathrm{MSG}$ 첨가군들의 $\mathrm{pH}$ 가 무첨가군에 비해 더 높은 것도 동일한 이유로 생각되며 섬애약쑥 추출액 자체의 $\mathrm{pH}$ 가 오 미자 추출액 보다는 높고, $\mathrm{MSG}$ 의 첨가량이 적어 그 차이는 더 적었던 것으로 판단된다.

\section{가용성 고형분 및 환원당의 함량 변화}

MSG를 첨가한 섬애약쑥 식혜를 유산균 발효한 발효물 의 가용성 고형분 및 환원당의 함량을 각각 정량한 결과는 Table 4-5와 같다. 가용성 고형분은 발효기간이 경과할수록 점차 감소하는 경향을 보였는데, $\mathrm{MSG}$ 를 첨가하지 않은 경우 가용성 고형분은 발효 전 $20.50{ }^{\circ} \mathrm{Brix}$ 이던 것이 발효 3 일 후에는 $19.80{ }^{\circ} \mathrm{Brix}$ 로 낮아졌고, MSG $1 \%$ 첨가군의 경우 $20.87{ }^{\circ} \mathrm{Brix}$ 이던 것이 $19.70{ }^{\circ} \mathrm{Brix}$ 로 낮아져 모든 시료 에서 발효 3 일차에 유의적으로 가장 낮았으나 평균값의 차이는 0.4-1.6 ${ }^{\circ} \mathrm{Brix}$ 의 범위로 변화가 크지 않았다.

연근과 도라지 당 추출 발효액의 농도를 $12{ }^{\circ} \mathrm{Brix}$ 로 조절 
한 후 유산균 발효하면서 변화를 측정한 결과 도라지의 경우 $12.0-12.1{ }^{\circ} \mathrm{Brix}$ 이던 것이 $11.5-11.7{ }^{\circ} \mathrm{Brix}$ 로 감소하여 통계적인 차이는 있었지만 가장 큰 차이를 보인 시료가 $0.5{ }^{\circ} \mathrm{Brix}$ 정도 감소하는 데 그쳐 그 차이는 크지 않았다는 Lee 등(26)의 보고와 혼합 과채 주스에 첨가한 당의 종류를 달리하여 9일간 유산균 발효하였을 때 가용성 고형분은 4일까지는 거의 변화가 없다가 그 이후 $1.3-2.0{ }^{\circ} \mathrm{Brix}$ 정도 감소하였다는 보고(24)는 본 연구의 결과와도 일치하는 경 향이었다.

환원당의 함량(Table 5)은 발효 전 14.01-15.46 mg/100
$\mathrm{mL}$ 이던 것이 발효 기간이 경과할수록 점차 감소하는 경향 을 보여 발효 3일에는 $13.26-14.49 \mathrm{mg} / 100 \mathrm{~mL}$ 의 범위로 감소하였다. $\mathrm{MSG}$ 의 첨가 비율에 따라서도 환원당의 함량 은 차이를 나타내었는데 발효 3일에 MSG $0.25 \%$ 첨가군의 경우 $13.82 \mathrm{~g} / 100 \mathrm{~mL}$ 였고 $1.0 \%$ 첨가군에서는 $14.49 \mathrm{~g} / 100$ $\mathrm{mL}$ 로 더 높아 $\mathrm{MSG}$ 의 첨가 비율이 높을수록 환원당의 함량 도 더 높았다.

본 연구의 결과 가용성 고형분은 감소하는 경향이었으나 그 절대 값은 차이가 크지 않았고, 환원당은 발효기간의 경과와 더불어 감소하는 경향을 보였는데 $\mathrm{MSG}$ 의 첨가비

Table 4. Changes in soluble solid content of lactic acid fermented Sikhye added with Seomaeyaksuk extract and MSG

$\left({ }^{\circ}\right.$ Brix)

\begin{tabular}{|c|c|c|c|c|}
\hline \multirow{2}{*}{$\begin{array}{l}\text { Fermentation period } \\
\text { (day) }\end{array}$} & \multicolumn{4}{|c|}{ MSG addition ratio (\%) } \\
\hline & 0 & 0.25 & 0.5 & 1.0 \\
\hline 0 & $20.50 \pm 0.01^{1) a 2) B 3}$ & $21.20 \pm 0.01^{\mathrm{cB}}$ & $21.50 \pm 0.01^{\mathrm{dB}}$ & $20.87 \pm 0.15^{\mathrm{bC}}$ \\
\hline 1 & $20.13 \pm 0.06^{\mathrm{aB}}$ & $20.77 \pm 0.06^{\mathrm{aA}}$ & $20.30 \pm 0.17^{\mathrm{aA}}$ & $20.20 \pm 0.01^{\mathrm{aB}}$ \\
\hline 2 & $19.83 \pm 0.06^{\mathrm{aA}}$ & $20.73 \pm 0.23^{\mathrm{cA}}$ & $19.87 \pm 0.32^{\mathrm{bA}}$ & $20.10 \pm 0.01^{\mathrm{bB}}$ \\
\hline 3 & $19.80 \pm 0.01^{\mathrm{bA}}$ & $20.80 \pm 0.01^{\mathrm{dA}}$ & $19.90 \pm 0.01^{\mathrm{cA}}$ & $19.70 \pm 0.01^{\mathrm{aA}}$ \\
\hline
\end{tabular}

${ }^{1)}$ Each value is a mean $\pm \mathrm{SD}$ of 5 samples.

${ }^{2) a-d}$ Means with different letters in the same row are significantly different at $\mathrm{p}<0.05$ by Duncan's multiple range test.

${ }^{3) A-D}$ Means with different letters in the same column are significantly different at $\mathrm{p}<0.05$ by Duncan's multiple range test.

Table 5. Changes in reducing sugar content of lactic acid fermented Sikhye added with Seomaeyaksuk extract and MSG

$(\mathrm{g} / 100 \mathrm{~mL})$

\begin{tabular}{|c|c|c|c|c|}
\hline \multirow{2}{*}{$\begin{array}{l}\text { Fermentation period } \\
\text { (day) }\end{array}$} & \multicolumn{4}{|c|}{ MSG addition ratio (\%) } \\
\hline & 0 & 0.25 & 0.5 & 1.0 \\
\hline 0 & $14.01 \pm 0.01^{12 \mathrm{a} 2 \mathrm{D} \mathrm{B} 3)}$ & $14.86 \pm 0.03^{\mathrm{bD}}$ & $15.14 \pm 0.05^{\mathrm{cD}}$ & $15.46 \pm 0.05^{\text {dI }}$ \\
\hline 1 & $13.70 \pm 0.07^{\mathrm{aC}}$ & $14.25 \pm 0.06^{\mathrm{bC}}$ & $14.77 \pm 0.01^{\complement C}$ & $14.98 \pm 0.04^{\mathrm{dc}}$ \\
\hline 2 & $13.55 \pm 0.04^{\mathrm{aB}}$ & $13.94 \pm 0.01^{\mathrm{bB}}$ & $14.05 \pm 0.02^{\mathrm{CB}}$ & $14.77 \pm 0.03^{\text {dा }}$ \\
\hline 3 & $13.26 \pm 0.04^{\mathrm{aA}}$ & $13.82 \pm 0.03^{\mathrm{bA}}$ & $13.93 \pm 0.04^{\mathrm{cA}}$ & $14.49 \pm 0.04^{\mathrm{d} A}$ \\
\hline
\end{tabular}

${ }^{1)}$ Each value is a mean \pm SD of 5 samples.

2)a-d Means with different letters in the same row are significantly different at $\mathrm{p}<0.05$ by Duncan's multiple range test.

${ }^{3) A-D}$ Means with different letters in the same column are significantly different at $\mathrm{p}<0.05$ by Duncan's multiple range test.

Table 6. Changes in GABA content of lactic acid fermented Sikhye added with Seomaeyaksuk extract and MSG

\begin{tabular}{|c|c|c|c|c|}
\hline \multirow{2}{*}{ Fermentation time (day) } & \multicolumn{4}{|c|}{ MSG addition ratio (\%) } \\
\hline & 0 & 0.25 & 0.5 & 1.0 \\
\hline 0 & $\mathrm{ND}^{1)}$ & $\mathrm{ND}$ & $\mathrm{ND}$ & $\mathrm{ND}$ \\
\hline 1 & $12.29 \pm 1.30^{22 \mathrm{a} 3) A 4)}$ & $101.25 \pm 1.88^{\mathrm{bA}}$ & $131.46 \pm 0.95^{\mathrm{cA}}$ & $162.92 \pm 0.18^{\mathrm{dA}}$ \\
\hline 2 & $34.48 \pm 0.18^{\mathrm{aB}}$ & $173.44 \pm 1.62^{\mathrm{bB}}$ & $201.88 \pm 3.31^{\mathrm{cB}}$ & $257.81 \pm 5.41^{\mathrm{dB}}$ \\
\hline 3 & $47.50 \pm 0.54^{\mathrm{aC}}$ & $200.42 \pm 6.86^{\mathrm{bC}}$ & $260.10 \pm 3.43^{\mathrm{cC}}$ & $354.38 \pm 1.62^{\mathrm{dC}}$ \\
\hline
\end{tabular}

${ }^{1)} \mathrm{ND}$, not detected.

${ }^{2)}$ Each value is a mean \pm SD of 5 samples.

${ }^{3) a-d}$ Means with different letters in the same row are significantly different at $\mathrm{p}<0.05$ by Duncan's multiple range test.

${ }^{4) A-D}$ Means with different letters in the same column are significantly different at $\mathrm{p}<0.05$ by Duncan's multiple range test. 
율이 높을수록 발효 완료 후 그 값이 더 높았다. 이는 유산균 이 발효과정에서 환원당을 주로 이용하지만 발효기간이 경과할수록 발효균의 생육에 따라 분해되는 당류가 보충됨 으로써 전체적인 고형분의 함량 변화에는 영향을 미치지 못한 결과로 추정된다.

\section{GABA 함량 변화}

유산균 발효 기간 동안 발효물 중의 GABA 함량을 정량 한 결과는 Table 6 과 같이 젖산균의 접종 직후에는 $\mathrm{GABA}$ 함량이 낮아 모든 시료에서 검출량 미만이었으나 발효 1 일 부터 그 함량은 증가하여 무첨가군에서도 $12.29 \mathrm{mg} / \mathrm{L}$ 가 검출되었으며 발효가 진행되면서 그 함량은 점차 증가하는 경향을 나타내었다. $\mathrm{MSG}$ 의 첨가농도가 높을수록 $\mathrm{GABA}$ 의 생성량도 증가하였는데, $\mathrm{GABA}$ 를 첨가하지 않은 대조군 의 경우에도 발효기간이 증가할수록 그 함량이 증가하여 식혜의 원료로 사용된 섬애약쑥과 맥아추출물 중의 글루탐 산이 젖산균에 의해 $\mathrm{GABA}$ 로 전환됨으로써 그 함량이 증가 한 것으로 판단된다. 첨가한 $\mathrm{MSG}$ 의 비율은 $0.25 \%$ 를 기준 으로 시료별로 각각 2 배씩 증가하였으나 실제 $\mathrm{GABA}$ 의 생성량은 발효 3일차를 기준으로 약 1.3-1.4배 증가하였다. 대조군의 경우 발효 1 일차에 비해 2 일차에 약 2.8 배가 증가 하였으며, 2 일차에서 비해 3 일차에는 약 1.4 배가 증가하였 는데, MSG 첨가군들의 경우 발효 2일차에 1.5-1.7배 증가하
였고, 발효 3일차에는 1.2-1.4배 정도 증가하여 $\mathrm{MSG}$ 의 첨가 비율이 높을수록, 발효기간이 경과할수록 $\mathrm{GABA}$ 의 생성율 은 오히려 더 낮았다. 하지만 GABA가 생성된 절대량은 $\mathrm{MSG}$ 의 첨가비율이 높을수록 더 높아 $1.0 \%$ 첨가군의 경우 발효 3일에 $354.38 \mathrm{mg} / \mathrm{L}$ 로 가장 높은 함량이었다. 이를 통 해 유산균에 의한 글루탐산의 GABA로의 전환율은 발효초 기에 높고 발효기간이 경과함에 따라 낮아지지만 생성된 $\mathrm{GABA}$ 의 양이 누적됨으로 인해 발효기간이 경과할수록 최종 생성량은 더 증가함을 알 수 있었다.

유산균 발효 과정에서 $\mathrm{GABA}$ 의 생산을 위해 전구물질로 첨가되는 $\mathrm{MSG}$ 는 세포내 탈탄산효소에 의해 $\mathrm{GABA}$ 로 전환 되는데, 산성화 스트레스에 대한 방어 수단으로 glutamate 로부터 효소적 반응에 의해 세포내 proton을 소비하면서 $\mathrm{GABA}$ 를 생성함으로써 발효물의 산도를 유지 또는 감소시 키는 것으로 알려져 있다(25,27).

\section{유리당의 함량 변화}

유산균 발효과정 중 유리당은 fructose, glucose 및 sucrose 가 검출되었는데, fructose는 발효 전 $0.15-0.18 \mathrm{~g} / 100 \mathrm{~mL}$ 이 던 것이 발효기간의 경과와 더불어 점차 감소하여 발효 3일 후에는 0.05-0.09 g/100 mL로 잔존율은 33-50\% 수준이 었으며, $\mathrm{MSG}$ 의 첨가량이 많을수록 잔존율은 더 낮았다 (Table 7). Glucose의 경우 일정한 경향 없이 불규칙한 증감

Table 7. Changes in free sugar content of lactic acid fermented Sikhye added with Seomaeyaksuk extract and MSG

$(\mathrm{g} / 100 \mathrm{~mL})$

\begin{tabular}{|c|c|c|c|c|c|}
\hline $\begin{array}{l}\text { MSG addition ratio } \\
(\%)\end{array}$ & $\begin{array}{l}\text { Fermentation period } \\
\text { (day) }\end{array}$ & Fructose & Glucose & Sucrose & Total \\
\hline \multirow{4}{*}{0} & 0 & $0.18 \pm 0.03^{\left.1 / a_{2}\right)(3)}$ & $0.97 \pm 0.07^{\mathrm{bAB}}$ & $5.51 \pm 0.16^{a B}$ & $6.66 \pm 2.88$ \\
\hline & 1 & $0.05 \pm 0.00^{\mathrm{aA}}$ & $0.71 \pm 0.10^{\mathrm{bA}}$ & $4.52 \pm 0.11^{\mathrm{aA}}$ & $5.28 \pm 2.41$ \\
\hline & 2 & $0.06 \pm 0.00^{\mathrm{aA}}$ & $0.80 \pm 0.11^{\mathrm{cA}}$ & $7.92 \pm 0.34^{\mathrm{bC}}$ & $8.78 \pm 4.34$ \\
\hline & 3 & $0.09 \pm 0.01^{\mathrm{bB}}$ & $1.03 \pm 0.12^{\mathrm{CB}}$ & $7.28 \pm 0.51^{\mathrm{CC}}$ & $8.40 \pm 3.91$ \\
\hline \multirow{4}{*}{0.25} & 0 & $0.15 \pm 0.03^{a B}$ & $1.08 \pm 0.08^{\mathrm{cB}}$ & $5.95 \pm 0.49^{\mathrm{aA}}$ & $7.18 \pm 3.12$ \\
\hline & 1 & $0.05 \pm 0.00^{\mathrm{aA}}$ & $0.93 \pm 0.10^{\mathrm{cAB}}$ & $8.20 \pm 0.40^{\mathrm{dC}}$ & $9.18 \pm 4.47$ \\
\hline & 2 & $0.27 \pm 0.03^{\mathrm{bC}}$ & $1.07 \pm 0.07^{\mathbb{B B}}$ & $8.36 \pm 0.40^{\mathrm{bC}}$ & $9.70 \pm 4.46$ \\
\hline & 3 & $0.06 \pm 0.01^{\mathrm{aA}}$ & $0.85 \pm 0.11^{\mathrm{bA}}$ & $7.32 \pm 0.31^{\mathrm{CB}}$ & $8.23 \pm 3.98$ \\
\hline \multirow{4}{*}{0.5} & 0 & $0.16 \pm 0.01^{a \mathrm{~B}}$ & $1.07 \pm 0.03^{\mathrm{dC}}$ & $5.99 \pm 0.17^{\mathrm{aA}}$ & $7.22 \pm 3.14$ \\
\hline & 1 & $0.05 \pm 0.00^{\mathrm{aA}}$ & $0.68 \pm 0.06^{\mathrm{abB}}$ & $7.41 \pm 0.43^{c B}$ & $8.14 \pm 4.08$ \\
\hline & 2 & $0.05 \pm 0.00^{\mathrm{aA}}$ & $0.54 \pm 0.07^{\mathrm{bA}}$ & $5.92 \pm 0.17^{\mathrm{aA}}$ & $6.51 \pm 3.26$ \\
\hline & 3 & $0.06 \pm 0.01^{\mathrm{aA}}$ & $0.77 \pm 0.09^{\mathrm{bB}}$ & $5.58 \pm 0.74^{\mathrm{bA}}$ & $6.41 \pm 3.00$ \\
\hline \multirow{4}{*}{1.0} & 0 & $0.15 \pm 0.01^{\mathrm{aB}}$ & $1.01 \pm 0.01^{\mathrm{aB}}$ & $5.70 \pm 0.07^{\mathrm{aB}}$ & $6.86 \pm 2.99$ \\
\hline & 1 & $0.06 \pm 0.03^{\mathrm{aA}}$ & $0.55 \pm 0.01^{\mathrm{D}}$ & $6.69 \pm 0.06^{6 \mathrm{D}}$ & $7.3 \pm 3.69$ \\
\hline & 2 & $0.05 \pm 0.00^{\mathrm{aA}}$ & $0.40 \pm 0.00^{\mathrm{aC}}$ & $5.90 \pm 0.11^{\mathrm{aC}}$ & $6.35 \pm 3.28$ \\
\hline & 3 & $0.05 \pm 0.00^{\mathrm{aA}}$ & $0.23 \pm 0.01^{\mathrm{aA}}$ & $4.06 \pm 0.00^{\mathrm{aA}}$ & $4.34 \pm 2.27$ \\
\hline
\end{tabular}

\footnotetext{
${ }^{1)}$ Each value is a mean \pm SD of 5 samples.

2)a-d Means with different letters in the same fermentation days are significantly different at $p<0.05$ by Duncan's multiple range test.

${ }^{3) A-D}$ Means with different letters in the same MSG added ratio are significantly different at $\mathrm{p}<0.05$ by Duncan's multiple range test.
} 
을 보였는데, MSG 무첨가군에서는 발효 1-2일에는 그 함량 이 다소 감소하였다가 발효 완료 후에는 발효 전에 비해 유의적인 차이가 없었다. 하지만 MSG 첨가군들에서는 발 효 전 $1.01-1.08 \mathrm{~g} / 100 \mathrm{~mL}$ 의 범위이던 것이 점차 감소하는 경향을 보여 발효 종료 후에는 $0.25-0.87 \mathrm{~g} / 100 \mathrm{~mL}$ 이었다. Sucrose는 발효 전 $5.51-5.99 \mathrm{~g} / 100 \mathrm{~mL}$ 이던 것이 발효 1 일에 증가하였다가 그 이후부터는 감소하는 경향을 보였다.

유산균은 일반적으로 당을 이용하여 젖산을 형성하는데 glucose, fructose와 같은 6탄당을 주로 이용하며 lactose 등 의 이당류 혹은 ribose 등의 오탄당 또한 대사에 이용하는데, 매실을 젖산 발효함에 있어 당을 보충하는 산 생성능은 fructose가 가장 적합하다고 보고되어 있다(1). 본 연구의 결과에서도 감소하는 경향을 보인 당류는 유산균의 생육에 이용되었을 것으로 추정할 수 있으며, 발효물 중의 MSG 첨가 비율이 높을수록 당류의 소비량이 더 많아짐을 확인할 수 있었다.

\section{유기산의 함량변화}

유산균 발효 기간 동안 유기산의 함량 변화를 분석한 결과는 Table 8 과 같다. 유기산은 총 7종이 검출되었는데, 총량은 발효 전에 $1,397.03-1,598.13 \mathrm{mg} / 100 \mathrm{~mL}$ 이던 것이 발효기간의 경과와 더불어 점차 그 함량이 증가하여 발효
3일에는 2,683.59-2,919.85 mg/100 mL로 증가하였다. 발효 초기의 유기산은 propionic acid의 함량이 가장 높아 $539.56-726.83 \mathrm{mg} / 100 \mathrm{~mL}$ 이었으며, 다음으로 succinic acid 가 349.18-441.29 mg/100 mL로 높은 함량이었다. 발효기간 이 경과함에 따라 propionic acid의 함량은 점차 감소하여 발효 3일에 449.60-89.42 mg/100 mL이었다. oxalic acid,citric acid 및 fumaric acid도 동일한 경향으로 발효기간 이 경과함에 따라 감소하였다. 발효기간이 경과함에 따라 lactic acid, acetic acid 및 succinic acid의 함량은 점차 증가하 였는데, 발효 3일에 그 함량은 succinic acid가 가장 높아 801.15-996.32 mg/100 mL이었다. 발효 초기에 52.93-69.35 $\mathrm{mg} / 100 \mathrm{~mL}$ 로 함량이 낮았던 lactic acid는 발효기간의 경과 와 더불어 가장 큰 폭으로 증가하여 발효 3 일 후에는 698.05-789.42 mg/100 mL이었다.

유산균의 대사산물로부터 생성되는 유기산은 맛, 향, 영 양적인 측면과 생육활성을 나타내는 중요한 지표인데, 유 산균 발효 시킨 감자 쥬스의 경우 이형 젖산발효로 인해 lactic acid와 acetic acid의 함량 증가가 현저하였다고 보고 되어 있다(28). 본 연구의 결과에서도 이와 유사한 경향으로 유산균의 이형발효로 인해 lactic acid 이외의 유기산 함량이 함께 증가한 것으로 추정된다.

Table 8. Changes in organic acid content of lactic acid fermented Sikhye added with Seomaeyaksuk extract and MSG

$(\mathrm{mg} / 100 \mathrm{~mL})$

\begin{tabular}{|c|c|c|c|c|c|c|c|c|c|}
\hline $\begin{array}{c}\text { MSG } \\
\text { addition } \\
\text { ratio }(\%)\end{array}$ & $\begin{array}{c}\text { Ferment. } \\
\text { period } \\
\text { (day) }\end{array}$ & Oxalic acid & Lactic acid & Acetic acid & Citric acid & Succinic acid & Fumaric acid & Propionic acid & Total \\
\hline \multirow{4}{*}{0} & 0 & $93.86 \pm 0.50^{1 \mathrm{b2} 2 \mathrm{D} 3)}$ & $54.25 \pm 6.40^{\mathrm{aA}}$ & $231.19 \pm 13.41^{\mathrm{aA}}$ & $27.66 \pm 1.02^{\mathrm{aC}}$ & $349.18 \pm 5.50^{\mathrm{aA}}$ & $1.08 \pm 0.05^{\mathrm{aC}}$ & $692.99 \pm 4.17^{\mathrm{bC}}$ & $1,450.21 \pm 8.57$ \\
\hline & 1 & $85.46 \pm 0.88^{b C}$ & $269.47 \pm 6.40^{\mathrm{aB}}$ & $649.72 \pm 13.12^{\mathrm{bB}}$ & $21.20 \pm 1.11^{\mathrm{bB}}$ & $719.95 \pm 5.94^{\mathrm{cB}}$ & $1.05 \pm 0.04^{\mathrm{cC}}$ & $695.13 \pm 10.05^{\mathrm{cC}^{\mathrm{C}}}$ & $2,441.98 \pm 11.22$ \\
\hline & 2 & $80.39 \pm 0.84^{\mathrm{bB}}$ & $612.19 \pm 9.24^{\mathrm{aC}}$ & $716.21 \pm 8.28^{\mathrm{cC}}$ & $16.30 \pm 1.64^{\mathrm{bA}}$ & $731.82 \pm 10.10^{\mathrm{bB}}$ & $0.80 \pm 0.03^{\mathrm{cB}}$ & $465.79 \pm 10.42^{c B}$ & $2,623.50 \pm 2.23$ \\
\hline & 3 & $65.50 \pm 0.38^{\mathrm{aA}}$ & $698.02 \pm 14.21^{a \mathrm{D}}$ & $794.66 \pm 5.38^{\mathrm{CD}}$ & $15.94 \pm 2.11^{\mathrm{bA}}$ & $801.15 \pm 11.47^{\mathrm{aC}}$ & $0.73 \pm 0.02^{\mathrm{bA}}$ & $449.60 \pm 4.53^{\mathrm{dA}}$ & $2,825.60 \pm 5.42$ \\
\hline \multirow{4}{*}{0.25} & 0 & $87.56 \pm 1.18^{\mathrm{aC}}$ & $57.88 \pm 2.26^{\mathrm{aA}}$ & $285.60 \pm 12.93^{\mathrm{bA}}$ & $25.76 \pm 0.93^{a \mathrm{~B}}$ & $379.30 \pm 12.87^{\mathrm{bA}}$ & $1.09 \pm 0.00^{\mathrm{aC}}$ & $691.49 \pm 4.55^{\mathrm{bB}}$ & $1,528.68 \pm 24.04$ \\
\hline & 1 & $78.14 \pm 0.40^{\mathrm{aB}}$ & $367.13 \pm 10.62^{6 \mathrm{~B}}$ & $482.72 \pm 14.62^{a \mathrm{~B}}$ & $19.96 \pm 2.99^{\mathrm{bA}}$ & $524.78 \pm 6.71^{\mathrm{aB}}$ & $0.81 \pm 0.02^{\mathrm{bB}}$ & $715.18 \pm 6.82^{\mathrm{dC}}$ & $2,188.72 \pm 22.16$ \\
\hline & 2 & $77.73 \pm 0.60^{\mathrm{aB}}$ & $678.35 \pm 11.84^{\mathrm{bC}}$ & $579.64 \pm 12.87^{\mathrm{aC}}$ & $19.65 \pm 3.00^{\mathrm{bA}}$ & $682.92 \pm 15.31^{a \mathrm{C}}$ & $0.74 \pm 0.01^{\mathrm{bA}}$ & $706.01 \pm 6.72^{\mathrm{dC}}$ & $2,745.04 \pm 6.27$ \\
\hline & 3 & $68.36 \pm 0.63^{\mathrm{bA}}$ & $699.46 \pm 11.10^{\mathrm{aD}}$ & $928.32 \pm 3.36^{\mathrm{dD}}$ & $16.73 \pm 1.81^{\mathrm{bA}}$ & $822.47 \pm 13.87^{6 \mathrm{D}}$ & $0.73 \pm 0.03^{\mathrm{bA}}$ & $383.78 \pm 4.29^{\mathrm{cA}}$ & $2,919.85 \pm 25.19$ \\
\hline \multirow{4}{*}{0.5} & 0 & $98.24 \pm 2.01^{\mathrm{cC}}$ & $69.35 \pm 10.23^{\mathrm{aA}}$ & $232.83 \pm 13.30^{\mathrm{aA}}$ & $28.53 \pm 2.18^{\mathrm{aC}}$ & $441.29 \pm 5.75^{\mathrm{cA}}$ & $1.06 \pm 0.06^{\mathrm{aD}}$ & $726.83 \pm 10.44^{\mathrm{cC}}$ & $1,598.13 \pm 23.09$ \\
\hline & 1 & $95.23 \pm 2.16^{\mathrm{cBC}}$ & $437.37 \pm 4.45^{\mathrm{cB}}$ & $692.98 \pm 2.14^{\mathrm{cB}}$ & $14.81 \pm 0.62^{\mathrm{aB}}$ & $661.40 \pm 0.40^{\mathrm{bB}}$ & $0.79 \pm 0.01^{\mathrm{bC}}$ & $411.14 \pm 1.04^{\mathrm{bB}}$ & $2,313.72 \pm 4.63$ \\
\hline & 2 & $92.42 \pm 1.19^{\mathrm{cB}}$ & $721.73 \pm 11.25^{\mathrm{cC}}$ & $713.24 \pm 13.39^{\mathrm{cC}}$ & $10.40 \pm 0.83^{\mathrm{aA}}$ & $790.96 \pm 1.23^{\mathrm{cC}}$ & $0.71 \pm 0.01^{\mathrm{bB}}$ & $398.47 \pm 5.38^{\mathrm{bB}}$ & $2,727.93 \pm 0.02$ \\
\hline & 3 & $80.38 \pm 1.24^{\mathrm{dA}}$ & $778.05 \pm 11.51^{6 \mathrm{D}}$ & $771.37 \pm 9.40^{\mathrm{bD}}$ & $9.34 \pm 0.55^{\mathrm{aA}}$ & $842.36 \pm 1.15^{\mathrm{cD}}$ & $0.21 \pm 0.02^{\mathrm{aA}}$ & $284.17 \pm 8.21^{\mathrm{bA}}$ & $2,765.88 \pm 32.08$ \\
\hline \multirow{4}{*}{1.0} & 0 & $97.89 \pm 1.21^{\mathrm{cD}}$ & $52.93 \pm 12.45^{\mathrm{aA}}$ & $288.72 \pm 11.41^{\mathrm{bA}}$ & $26.23 \pm 1.22^{2 \mathrm{C}}$ & $390.69 \pm 6.92^{\mathrm{bA}}$ & $1.01 \pm 0.03^{\mathrm{aD}}$ & $539.56 \pm 14.78^{\mathrm{aD}}$ & $1,397.03 \pm 47.96$ \\
\hline & 1 & $94.60 \pm 0.54^{\mathrm{cC}}$ & $610.14 \pm 0.70^{\mathrm{dB}}$ & $486.04 \pm 7.77^{\mathrm{aB}}$ & $15.22 \pm 1.11^{\mathrm{aB}}$ & $781.31 \pm 8.28^{\mathrm{dB}}$ & $0.66 \pm 0.04^{\mathrm{aC}}$ & $224.25 \pm 11.78^{\mathrm{aC}}$ & $2,212.22 \pm 11.44$ \\
\hline & 2 & $91.66 \pm 1.50^{\mathrm{cB}}$ & $788.84 \pm 13.55^{\mathrm{dC}}$ & $604.17 \pm 7.54^{\mathrm{bC}}$ & $11.40 \pm 1.02^{\mathrm{aA}}$ & $894.05 \pm 19.79^{\mathrm{dC}}$ & $0.57 \pm 0.05^{\mathrm{aB}}$ & $139.56 \pm 10.18^{\mathrm{aB}}$ & $2,530.25 \pm 14.05$ \\
\hline & 3 & $72.69 \pm 0.50^{\mathrm{cA}}$ & $789.42 \pm 10.70^{\mathrm{bC}}$ & $725.23 \pm 8.04^{a D}$ & $10.34 \pm 1.55^{\mathrm{aA}}$ & $996.32 \pm 5.73^{\mathbb{d D}}$ & $0.17 \pm 0.02^{\mathrm{aA}}$ & $89.42 \pm 9.24^{\mathrm{aA}}$ & $2,683.59 \pm 23.32$ \\
\hline
\end{tabular}

\footnotetext{
${ }^{1)}$ Each value is a mean $\pm \mathrm{SD}$ of 3 samples.

2)ad-d Means with different letters in the same fermentation days are significantly different at $p<0.05$ by Duncan's multiple range test.

${ }^{3) A-D}$ Means with different letters in the same MSG added ratio are significantly different at $p<0.05$ by Duncan's multiple range test.
} 
유산균 발효물의 총 페놀화합물 함량 및 $\mathrm{DPPH}$ 라디칼 소거활성

MSG의 첨가량을 달리하여 제조한 유산균 발효물을 3 일 간 젖산 발효한 후 총 페놀화합물 함량을 분석한 결과(Fig. 3) $\mathrm{MSG}$ 를 $0.25 \%$ 첨가한 경우에는 $\mathrm{MSG}$ 를 첨가하지 않은 대조군에 비해 오히려 그 함량이 더 낮았으며, $0.5 \%$ 첨가군 은 $31.65 \mathrm{mg} / \mathrm{g}$ 으로 가장 함량이 높았다.

연근과 도라지 당추출액을 3종류의 유산균으로 발효한 후 총 페놀화합물의 함량을 분석한 결과 연근의 경우 모든 시료의 총 페놀화합물 함량은 대조군에 비해 오히려 더 낮았으며, 도라지 당 추출액도 통계적인 유의차를 나타내 지 않았다는 보고(26)는 본 연구와도 일부 유사한 경향이었 다. 품종별 감자 주스를 유산균 발효한 후 총 페놀화합물의 함량을 분석한 결과에 따르면 발효 후에 그 함량이 감소하 거나 증가하였는데 통계적인 유의차는 없었으며, 플라보노 이드 함량은 발효과정을 거치면서 유의적으로 그 함량이 증가하는 것으로 보고되어 있다(28).

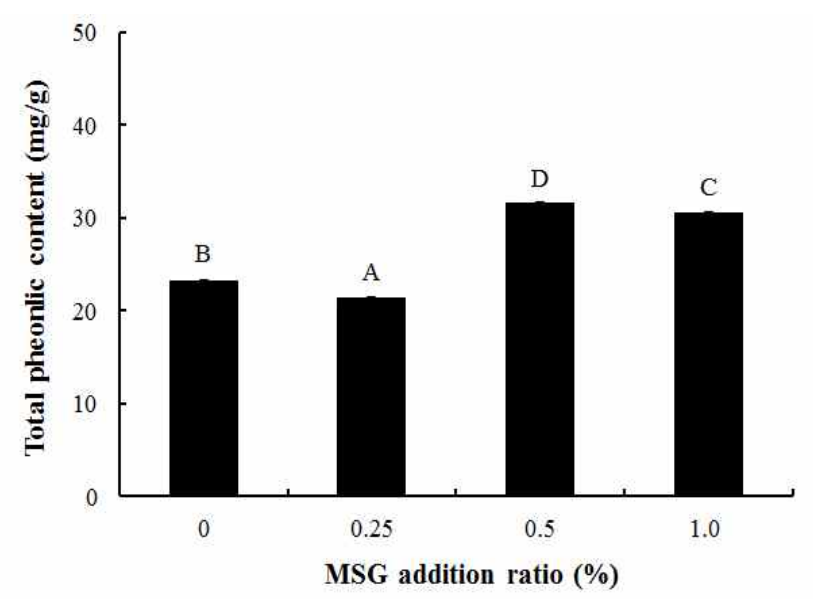

Fig 3. Changes in total polyphenol compounds of lactic acid fermented Sikhye added with Seomaeyaksuk extract and MSG.

${ }^{A-D}$ Means with different letters on bars are significantly different at $\mathrm{p}<0.05$ by Duncan's multiple range test.

발효 완료된 유산균 발효물의 DPPH 라디칼 소거활성을 평가한 결과는 Fig. 4 와 같다. MSG $0.25 \%$ 첨가군의 $\mathrm{DPPH}$ 라디칼 소거활성은 무첨가군에 비해서도 유의적으로 낮았 으나 $0.5 \%$ 및 $1.0 \%$ 첨가군은 각각 $88.79 \%$ 와 $87.63 \%$ 로 높은 활성을 나타내었다.

$\mathrm{DPPH}$ 라디칼 소거활성은 총 페놀화합물의 함량과 정의 상관관계를 가지는 것으로 알려져 있는데 본 연구의 결과에 서도 동일한 경향을 나타내었다. 상대적으로 총 페놀화합 물의 함량이 낮았던 $\mathrm{MSG}$ 무첨가군이나 $0.25 \%$ 첨가군의 경우도 $\mathrm{DPPH}$ 라디칼 소거활성은 각각 $81.73 \%$ 와 $76.69 \%$ 로 높았는데 이는 총 페놀화합물 이외에 유기산 등 유산균 발효 과정에서 생성된 물질들이 영향을 미쳤기 때문으로 추정된다.
약초 추출액을 이용한 한방 감주를 유산균 발효 시켰을 때 전자공여능은 총 페놀화합물의 함량이 약간 감소함에도 불구하고 일정하게 유지되었는데, 이는 유산균 발효 중에 생성된 유기산이 carboxyl기에 음전하를 띄고 있어 전자를 공여하기 때문이라는 보고가 있다(2).

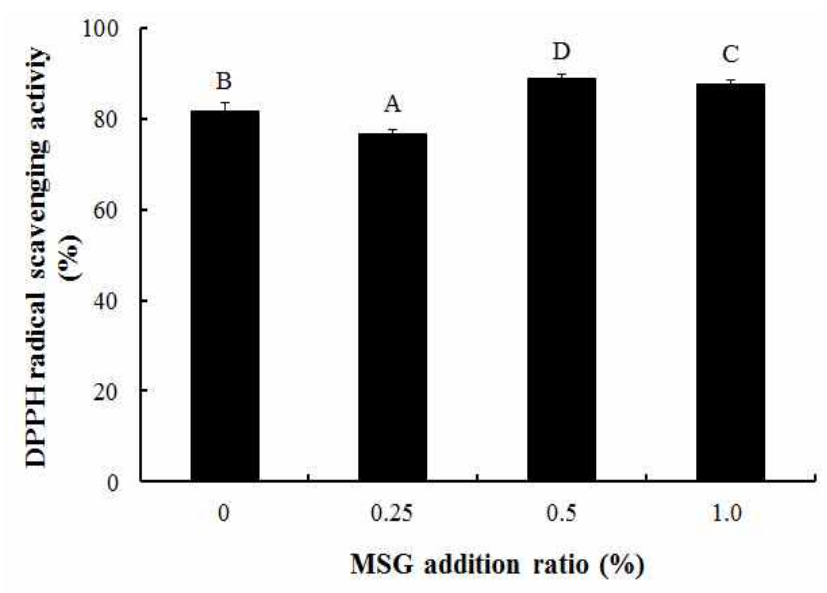

Fig. 4. Changes in DPPH radical scavenging activity of lactic acid fermented Sikhye added with Seomaeyaksuk extract and MSG.

${ }^{A-D}$ Means with different letters on bars are significantly different at $p<0.05$ by Duncan's multiple range test.

\section{요 약}

$\mathrm{GABA}$ 함량이 증가된 섬애약쑥 발효물의 제조를 위하여 섬애약쑥 추출물을 $15 \%$ 첨가하여 제조한 식혜에 $\mathrm{MSG}$ 를 $0,0.25,0.5$ 및 $1.0 \%$ 첨가하고, Lactobacillus brevis (KI271266)를 접종하여 3일간 발효하면서 일자별로 시료를 취해 이화학적 특성을 분석하였다. 발효기간이 경과할수록 탁도는 점차 감소하였고, 명도와 황색도는 증가하였고, 적 색도는 감소하는 경향이었다. 가용성고형분도 점차 낮아져 발효 3 일에는 $19.70-20.80{ }^{\circ} \mathrm{Brix}$ 의 범위였다. 환원당의 함량 은 $\mathrm{MSG}$ 의 첨가량이 많을수록 더 높았는데, 발효기간이 경과할수록 감소하는 경향이었다. $\mathrm{pH}$ 는 4.65-4.83이던 것 이 발효 3 일 후에는 3.15-3.68로 낮아졌다. $\mathrm{MSG}$ 의 첨가농도 가 높을수록 $\mathrm{GABA}$ 의 함량도 높았으며, 발효기간이 경과할 수록 그 함량도 증가하여 MSG $1.0 \%$ 첨가군에서는 354.38 $\mathrm{mg} / \mathrm{L}$ 로 가장 높은 함량이었다. Fructose, glucose 및 sucrose 는 발효 전에 비해 3일간 발효 후에 $50-67 \%$ 가 감소하였다. 유기산 중 propionic acid, oxalic acid, citric acid 및 fumaric acid의 함량은 발효기간의 경과와 더불어 감소하였고, lactic acid, acetic acid, succinic acid의 함량은 점차 증가하였는데, lactic acid의 증가폭이 가장 컸다. 3 일간 발효가 완료된 발효 물 중의 총 페놀화합물의 함량 및 $\mathrm{DPPH}$ 라디칼 소거활성은 동일한 경향으로 $\mathrm{MSG} 0.5 \%$ 첨가군이 유의적으로 가장 높았고, 다음으로 $1.0 \%$ 첨가군이었다. 이상의 결과로부터 
섬애약쑥 유산균 발효물 제조시 MSG를 첨가함으로써 발 효물의 이화학적 특성에는 영향을 미치지 않으면서 GABA 의 함량 증가가 가능함을 확인할 수 있었다.

\section{감사의 글}

본 연구는 산업통상자원부와 한국산업기술진흥원의 지 역주력산업육성 기술개발 사업(과제번호: R0004407)으로 으로 수행된 연구결과 입니다.

\section{References}

1. Hwang JY (2008) Optimization of the lactic acid fermentation of Maesil (Prunus mume). Korean J Food Nutr, 21, 391-396

2. Cho KM, Ahn BY, Seo WT (2008) Lactic acid fermentation of Gamju manufactured using medicinal herb decoction. Korean J Food Sci Technol, 40, 649-655

3. Jin HS (2001) Lactic acid fermentation of chestnut broth. Korean J Appl Microbiol Biotechnol, 29, 162-168

4. Jo SJ, Oh SM, Jang EK, Hwang K, Lee SP (2008) Physicochemical properties of carrot juice fermented by Leuconostoc mesenteroides SM. J Korean Soc Food Sci Nutr, 37, 210-216

5. Jeon JM, Choi SK, Kim YJ, Jang SJ, Cheon JW, Lee HS (2011) Antioxidant and antiaging effect of ginseng berry extract fermented by lactic acid bacteria. J Soc Cosmet Scientists Korea, 37, 75-81

6. Ryu IH, Kwon TO (2013) Functional quality characteristics of extracts by sugar-leaching and lactic acid fermentation of mulberry leaves (Morus alba L.). J Seric Entomol Sci, 51, 164-172

7. Park KB, Oh SH (2007) Cloning, sequencing and expression of a novel glutamate decarboxylase gene from a newly isolated lactic acid bacterium, Lactobacillus brevis OPK-3. Bioresource Technol, 98, 312-319

8. Nomura M, Nakajima I, Fujita Y, Kobayashi M, Kimoto H, Suzuki I, Aso H (1999) Lactococcus lactis contains only one glutamate decarboxylase gene. Microbiology, $145,1375-1380$

9. Krogsgaard-Larsen P (1989) GABA receptors. In: Receptor phamacology and function. Williams $M$, Glennon RA, Timmermans PMWM (editor), Marcel Dekker Inc, New York, NY, Korea, p 349-383

10. Mody I, DeKoninck Y, Otis TS, Soltesz I (1994) Bringing the cleft at GABA synapses in the brain. Trends Neurosci, $17,517-525$

11. Lim SD, Kim KS (2009) Effects and utilization of GABA Korean J Dairy Sci Technol, 27, 45-51

12. Kono I, Himeno K (2000) Changes in $\gamma$-aminobutyric acid content during beni-koji making. Biosci Biotechnol Biochem, 64, 617-619

13. Saikusa T, Horino T, Moki Y (1994) Accumulation of $\gamma$-aminobutyric acid (GABA) in the germ during water soaking. Biosci Biotechnol Biochem, 58, 2291-2292

14. Bown AW, Shelp BJ (1997) The metabolism and function of $x$-aminobutyric acid. Plant Physiol, 115, 1-5

15. Miller LP, Walters JR, Martin DL (1977) Post-mortem changes implicate adenine nucleotides and pyridoxal-5'phosphate in regulation of brain glutamate decarboxylase. Nature, 266, 847-848

16. Kang TJ, Oh SH (2007) Generation and utilization of GABA. BioWave, 9, 1-18

17. https://www.khidi.or.kr (2007) GABA enhanced functional food material production technology. Issue Report, 3, 86-97

18. Suk MH (2002) Explanation of function of GABA and possibility of development of new materia. Bulletin of Food Technol, 15, 81-85

19. Tsushida T, Murai T (1987) Conversion of glutamic acid to $\gamma$-aminobutyric acid in tea reaves under anaerobic conditions. Agric Biol Chem, 51, 2865-2871

20. Blankenhorn D, Phillips J, Slonczewski JL (1999) Acidand base-induced proteins during aerobic and anaerobic growth of Escherichia coli revealed by two-dimensional gel electrophoresis. J Bacteriol, 181, 2209-2216

21. Park SY, Kim KS, Lee MK, Lim SD (2013) Physiological characteristics and GABA production of Lactobacillus plantarum K255 isolated from kimchi. Korean J Food Sci An, 33, 595-602

22. Gutfinger T (1981) Polyphenols in olive oils. J Am Oil Chem Soc, 58, 966-968

23. Blois MS (1958) Antioxidant determination by the use of a stable free radical. Nature, 181, 1199-1200

24. Kim SY, Choi EH (2002) Optimization for the lactic acid fermentation of mixed fruit and vegetable juice. Korean J Food Sci Technol, 34, 303-310

25. Lee HS, Kwon SY, Lee SO, Lee SP (2016) Production of fermented Omija (Schizandra chinensis) beverage fortified with high content of gamma-amino butyric acid using Lactobacillus plantarum Korean J Food Preserv, $23,326-334$ 
26. Lee KS, Kim JN, Chung HC (2015) Study on anti-oxidative activities and beverage perferences relating to fermented lotus roots and Platycodon grandiflorum extracts with sugar through lactic acid fermentation. J East Asion Soc Dietary Life, 25, 183-192
27. Feehily C, Karatzas KAG (2013) Role of glutamate metabolism in bacterial responses towards acid and other stresses. J Appl Microbiol, 114, 11-24

28. Kim NJ, Yoon KY (2013) Qualities and antioxidant activity of lactic acid fermented-potato Juice. J Korean Soc Food Sci Nutr, 42, 542-549 